УДК 373.21: 37.015.31.7

(C) Штефан М.В., 2019 p.

http://orcid.org/0000-0002-0304-1567

DOI: $10.34142 / 23128046.2019 .47 .18$

M. В. Шmeфан

\title{
ЗМІСТ ПОНЯТТЯ ХУДОЖНЬО-ПРОДУКТИВНОї ДІЯЛЬНОСТІ ДІТЕЙ СТАРШОГО ДОШКІЛЬНОГО ВІКУ
}

Стаття присвячена аналізу визначення ключової категорії дослідження - художньо-продуктивна діяльність дитини старшого дошкільного віку. Проведено науковий аналіз ступеня розробки проблеми фахівиями. Указано, що формування компетенцій художньо-продуктивної діяльності дитини визначено пріоритетом державної освітньої політики. Цей вид діяльності є основою загального розвитку дитини, впливає на розв'язання завдань усіх напрямів виховання. У ході дослідження визначено психологічний базис поняття, яке вивчається. Зокрема, акцентовано увагу на наукових узагальненнях Л. Виготського. Зазначено, що діяльність дитини старшого дошкільного віку - ие активний процес взаємодї дитини 3 навколишнім світом. Тому художньо-продуктивна діяльність у иььому вічі набуває широкого вжитку. У статті на підставі аналізу наукових праць В. Ворожбіт виокремлено загальноиіннісний аспект художньо-продуктивної діяльності дитини.

Конкретизовано, щзо в основі художньо-продуктивної діяльності лежить створення художнього образу. Образ у цьому контексті виступає як характеристика творчого мислення автора-мития. Також указано, щзо образ слугує своєрідним підсумком иього мислення, закріплений у художньому продукті. $\quad$ у художньо-продуктивній діяльності образ проявлясться $i$ як сприйняття-переживання його глядачем, читачем, слухачем. Художній образ виступає, як естетична, иілісно-конкретна форма відображення реального світу.

У статті наголошено увагу на тому, що вихователь дає орієнтир, спрямовує дитину на життєвій успіх, продуктивну діяльність. Аналіз матеріалів дослідження засвідчив, щзо змістовна суть художньопродуктивної діяльності - це використання художніх засобів. Форми прояву художньо-продуктивної діяльності відбуваються на перетині інших видів діяльності: продуктивної, художньої, предметно-практичної, художнютворчої, технічної, художньо-естетичної. Результатом художньопродуктивної діяльності є кінцевий продукт, який впливає на формування життєвої компетентності, пронизує усі напрями виховання.

Новизна визначення поняття «художньо-продуктивна діяльність» забезпечується інтеграційним підходом у визначенні сутнісних компонентів. Автором зазначено, щзо продуктивна діяльність - ще процес створення 
кінцевого матеріального продукту (малюнок, виріб з пластиліну, будівництво будівель). Процес створення передбачає побудову образу, в якому задіяні мислення, уява, пам'ять. До продуктивної діяльності включають образотворчу і конструктивну.

Ключові слова: виховання, розвиток, вихователь, діяльність, художньо-продуктивна діяльність, образ, дитина, старший дошкільний вік.

Shtefan M. V. Content of the concept of artistic and productive activity of senior preschool children. The article is devoted to the analysis of the definition of the key category of the research, which is artistic and productive activity of a senior preschooler. The scientific analysis of the degree of the problem development has been carried out by specialists. It is stated that the formation of competencies of the child's artistic and productive activity is considered as a priority of the state educational policy. This activity type is the basis of the child's overall development, influences on the solving of the tasks of all areas of education. In the course of the research the psychological basis of the concept under study has been determined. In particular, attention is drawn to the scientific generalizations of L. Vyhotskyi. It is noted that the activity of a senior preschooler is an active process of interaction of a child with the outside world. Therefore, artistic and productive activity at this age is becoming widely used. In the article, based on the analysis of the scientific works of $V$. Vorozhbit, the valuable aspect of artistic and productive activity of the child has been highlighted.

It is specified that the basis of artistic and productive activity is the creation of a word picture. The world picture in this context is a characteristic of the creative thinking of the artist. It is also stated that the word picture is a kind of summary of this thinking, embedded in the artistic product. In artistic and productive activities, the word picture also manifests itself as the perception and experience of its viewer, reader, listener. The word picture is as an aesthetic, holistic and concrete form of reflection of the real world.

The article emphasizes that the educator provides guidance, directs the child to life success, productive activity. The analysis of the research materials has showed that the essence of artistic and productive activity is the use of artistic means. Forms of the expression of artistic and productive activity occur at the intersection of other activities: productive, artistic, subject and practical, artistic and creative, technical, artistic and aesthetic. The result of artistic and productive activity is the final product, which influences the formation of vital competence, permeates all directions of education.

The novelty of the definition of "artistic and productive activity" is provided by an integrative approach in defining the essential components. The author states that productive activity is the process of creating the final material product (drawing, plasticine craft, building construction of $s$ ). The process of creation involves the construction of an image which includes thinking, imagination, memory. Productive activities include visual and constructive. 
Keywords: education, development, educator, activity, artistic and productive activity, word picture, child, senior preschool age.

Вступ. Загальні тенденції розвитку сучасного суспільства, а саме: глобалізація, демографічні процеси, розвиток інформаційних технологій, призводять до суттєвих змін у освітніх системах світу. Формується нова модель, в основі якої лежить людський капітал. Ключовим чинником освітніх реформ у XXI столітті виступають творчі здібності особистості. Формування творчих навичок відбувається з дошкільного віку через включення дитини у різноманітні види художньо-продуктивної діяльності. Але, на жаль, під впливом і популяризацією інформаційних технологій більшість сучасних батьків опікуються логіко-математичним і мовленнєвим розвитком дитини, використовуючи традиційні прийоми, характерні для початкової школи: навчання читати і письма. При цьому недооцінюють такий від діяльності як художньо-продуктивний. А саме ця діяльність сприяє становленню духовного світу дитини, виробленню іiі естетичних смаків, життєвих цінностей.

Звичайно, під час художньо-продуктивної діяльності дитина ознайомлюється 3 творами мистецтва, створює продукт за зразком і додає власні деталі до свого виробу.

Багатогранна дитяча художньо-продуктивна діяльність $є$ передумовою розвитку творчих здібностей i життєвої компетенції дитини старшого дошкільного віку.

Метою статті $є$ уточнення сутності поняття художньо-продуктивної діяльності дітей старшого дошкільного віку.

Методи дослідження. Для розв'язання питання щодо визначення художньо-продуктивної діяльності були використанні теоретичні методи: вивчення психолого-педагогічної літератури, аналіз, систематизація, узагальнення - для визначення провідної категорії дослідження i виокремлення іiі у нормативно-законодавчій базі з дошкільної освіти.

Результати. Проведене дослідження засвідчило, що нормативноправові документи у галузі дошкільної освіти - Закон України «Про дошкільну освіту», Базовий компонент дошкільної освіти, чинні освітні програми - утверджують погляд на формування життєздатної, гнучкої, свідомої, творчої людини. Тому актуальним $є$ широке коло питань, які стосуються розкриття потенційних здібностей дітей старшого дошкільного віку у різних видах художньо-продуктивної діяльності, а саме: образотворчій, музичній, театральній, літературній. Освітні програми для дошкільної освіти визначають сім освітніх ліній. Художньо-продуктивна діяльність належить 
до освітньої лінії «Дитина у світі культури» (Derzhavnyi Bazovyi komponent doshkilnoi osvity v Ukraini (nova redaktsiia), 2016). Під час планування освітнього процесу для старшого дошкільного віку передбачено п’ять занять 3 художньо-продуктивної діяльності на тиждень тривалістю 25 хвилин (Nakaz Ministerstva osvity i nauky Ukrainy, 2015, April 20).

Варто наголосити, що діяльність дитини старшого дошкільного віку це активний процес взаємодії дитини з навколишнім світом. I сьогодні не втратили своєї актуальності результати розвідок психолога С. Рубінштейна, який діяльність людини розглядав як процес, за допомогою якого реалізується певне ставлення людей до навколишнього світу, до завдань, які висуває життя. Адже людина і діяльність нерозривно пов'язані між собою (Rubinshtejn, 2000). У діяльності розкриваються і формуються розумові здібності людини, творча уява, емоційно-естетичне ставлення до довкілля, світогляд. Взагалі, діяльність людини пов'язана з соціумом, із середовищем, яке формує людина відповідно до своєї діяльності. Метою дії, як відомо, $є$ задоволення потреб дитини старшого дошкільного віку. Безперечно, людина формує середовище через свої дії. Діяльність дитини складається з дій.

У психології визначають фізичні (зовнішні) дії з предметом і розумові (внутрішні) дії 3 відображенням (образами) предметів. Внутрішні дії формуються на основі зовнішніх. Вирішальне значення для загального розвитку має діяльність. Безперечно, що у діяльності дитини формуються усі види мислення: наочно-дійове, наочно-образне й абстрактне. Так, наочнодійове мислення характерне для дітей раннього віку. У перші роки життя дитина аналізує і синтезує об'єкти, що пізнає, об’єднуючи їх, порівнюючи між собою за сенсорними еталонами кольору, форми, величини, смаку тощо. Наочне-дійове мислення слугує основою для розвитку наочно-образного мислення, яке характерне для дітей дошкільників 3-7 років. Як стверджують О. Степанов та М. Фіцула, наочне-образне мислення - «...це мислення образами, уявленнями, перетворення ситуації в образні форми. Воно виникає тоді, коли у дитини є достатній досвід практичних дій i, замість реальних, вона вдається до розумових спроб змінити ситуацію, уявляючи необхідні дії й одержані результати» (Stepanov \& Fitsula, 2005).

Адже цей вид мислення є основою дошкільного віку і відмінною рисою цього мислення виступають «образи» $\mathrm{i}$ «уява». У цей віковий період активно розвивається наочно-образне мислення. I необхідною умовою $є$ втілення образів у продукт, реалізація образів у ігровій діяльності, насичування і подання матеріалу, який спонукає створювати позитивно-емоційні, яскраві образи предметів, вчинків, дій. У подальшому кожний образ дитина використовує у повсякденному житті як в повній мірі, так і комбінує їх. 
Наприклад, знаючи, що рослини і тварини не розмовляють і не розуміють людське мовлення, дитина певний час вважає, що рослини і тварини можуть розмовляти пошепки або тільки з дітьми, вони допомагають знайти вихід із складних ситуаціях. Це уявлення у дітей складається з набутого досвіду, а саме: шляхом спостереження за об'єктом у довкіллі, виконання практичних дій з об'єктом, розповіді казок, переглядання доброзичливих мультфільмів. Це лише декілька факторів, які впливають на формування образу і розвиток уяви. Окремі образи залишаються і супроводжують вже дорослу людину усе життя. Чарівний світ, який дитина власноруч створює, має величезний вплив на становлення ії особистісних ціннісних категорій у подальшому житті. У цьому ми погоджуємося $з$ дослідником В. Ворожбіт (Vorozhbit, 2012).

Разом 3 тим, зазначимо, що основою формування абстрактного мислення є наочно-образне, наочно-дійове. Абстрактне мислення характерне для дітей 8-го року життя і супроводжується вже навчальною діяльністю. Тому для того, щоб був фундамент для формування абстрактного мислення не можна пропускати перші два види мислення. Звісно, усі три види мислення 3 віком тільки ускладнюються і взаємопов'язані між собою, проявляються у життєвій і професійній діяльності людини.

Розглядаючи сутнісний аспект дослідження, зазначимо, що в основі художньо-продуктивної діяльності лежить створення художнього образу. Образ виступає як характеристика творчого мислення автора-митця; образ як підсумок цього мислення, закріплений в художньому продукті; образ - як сприйняття-переживання його глядачем, читачем, слухачем. Художній образ виступає, як естетична, цілісно-конкретна форма відображення реального світу. Художній образ нерозривно пов'язаний із мистецтвом. Мистецтво виступає як інструмент через який людина відображає дійсність (Levchuk, 2005).

Досвід і педагогічна практика підтверджують, не уявивши результати кінцевого продукту, не можна розпочати зовнішні дії щодо створення продукту. Під час створення образу майбутнього продукту одночасно розвиваються психічні процеси: фантазія і уява. У цьому спираємося на позиції провідних учених-психологів - Л. Виготського та Л. Венгера, що основою творчої діяльності є розвиток уяви і фантазії (Vygotskij, 1997).

У контексті обраної проблеми зауважимо, що художній образ притаманний для музичної, образотворчої, театральної і літературної діяльності. Так, у музичній діяльності звук (мелодія) є засобом формування художнього образу. Мелодія спрямована на емоційну сферу дитини. Дитина вчиться сприймати і емоційно відгукуватися на музику. Музику розрізнюють за характером, темпом, динамікою і регістром. Під час прослуховування 
музики у дитини виникає образ, який вона може висловити через свій рух, малюнок або розповідь про свої враження від почутої музики.

Так, сумна мелодія може сформувати у дитини образ дощової погоди, а ритмічна і весела - образ сонячної погоди. Під час заняття вихователь, музичний керівник супроводжує мелодію певними діями: використовує демонстраційний матеріал, пластичні рухи, художнє слово, які відповідають характеру мелодії (Ponimanska, 2013). Під впливом цих факторів формується не тільки образ, а й стан, емоції (сум, радість, інтерес, подив, страх).

Художній образ у літературній діяльності створюється за допомогою слова. Для літературної діяльності характерно розуміння дітьми змісту художнього (літературного) твору, переказ, відповіді на запитання, продовження казки чи оповідання за власним варіантом. Важливим аспектом для формування художнього образу $\epsilon$ використання ілюстрацій, які відповідають змісту твору. За допомогою слова можна надати характеристику персонажу, оцінити його вчинки, передати красу навколишнього світу. Важливим є використання різноманітних метафор, фразеологізмів, образного прислів'я. Емоційне забарвлення слів, які передають почуття й емоції, сприяє формуванню різноманітних образів, вчить дітей відрізняти гарні вчинки від поганих, бути чемними. Літературна діяльність сприяє розвитку дитячого мовлення і пам'яті, наслідуванню рис улюблених персонажів.

Театральна діяльність інтегрує музичну, хореографічну і літературну діяльність. Театральна діяльність є однією з складових ігрової діяльності дітей старшого дошкільного віку. Адже через самостійні, театралізовані ігри діти передають характерні особливості художнього образу і переносять набуті уявлення у грі у життєві ситуації. Діти під керівництвом вихователя розглядають сюжетний малюнок. Потім вихователь дає завдання подумки продовжити чи дати характеристику, опис події, зображених на малюнку. За допомогою театральних засобів (імітація, наслідування, елементи пластики, міміки, інтонування, діалогу, розповіді) реалізувати творчий задум.

Цікаво, найпростіший i найдоступніший засіб втілення образу у кінцевий матеріальний продукт відбувається тоді, коли дитина використовує навички в образотворчій діяльності: малюванні, ліпленні, аплікації, конструюванні (Derzhavnyi Bazovyi komponent doshkilnoi osvity v Ukraini (nova redaktsiia), 2016). Тобто відбувається моделювання продукту за образом. Так, під час сюжетного малювання «Чарівний осінній ліс», вихователь нагадує дітям як звучить осінній дощ, яка мелодія відповідає стану погоди, якими словами можна описати характер погоди, що відчуває природа, про що говорять птахи і дерева, коли іде дощ. Усі ці запитання, 
бесіди допомагають дитині проявляти уяву, розвивати фантазію, активізувати набуті образи і додати до них свої власні деталі й емоції.

За допомогою кольору, лінії, форми дитини вчиться виражати $\mathrm{i}$ втілювати свій образ, своє враження i ставлення до довкілля. Для моделювання i створення продукту необхідною умовою $\epsilon$ володіння технічними навичками: умінням правильно тримати пензлик, олівець, фломастер, крейду. Вміти в малюванні застосовувати різноманітні лінії (прямі, хвилясті), форми (коло, квадрат, трикутник, прямокутник) і регулювати силу натиску для створення малюнку. У ліпленні важливо вміти застосовувати такі прийоми, як: скачування, розкачування, сплющування, прищипування, згладжування, відтягування. Володіти способами ліпленням: конструктивним, пластичним, комбінованим. Для виробів із пластичного матеріалу (глина, пластилін, солоне тісто) характерний об’єм. Для аплікації необхідною умовою є вміти і вдосконалювати навички володіння ножицями, вирізуванням форм криволінійного контуру, використовувати симетричне вирізання з паперу.

Зазначені технічні навички у різних видах образотворчої діяльності розвивають дрібну моторику, точність рухів, сприяють розвитку узгоджених дій зорового і рухового аналізаторів. Усе це сукупно формує сприятливі умови для підготовки руки дитини до письма. Такі види діяльності активізують і спонукають дитину використовувати різноманітний художній матеріал для створення сюжетного задуму i, разом із тим, активно розвивають навички планування і самооцінювання художньо-продуктивної діяльності.

Отже, продуктивна діяльність - це процес створення кінцевого матеріального продукту (малюнок, виріб із пластиліну, будівництво будівель). Процес створення передбачає побудову образу, в якому задіяні мислення, уява, пам'ять. До продуктивної діяльності включають образотворчу і конструктивну.

У сучасному освітньому просторі постає питання щодо допомоги $\mathrm{i}$ методів керівництва під час художньо-продуктивної діяльності дітей старшого дошкільного віку. Це питання залишається дискусійним. Одні педагоги пропонують не надавати дітям допомоги, а дозволити свободу у своїх діях, а саме: не виправляти їх під час малювання, ліплення, аплікації, а, навпаки, спонукати автора виробу знаходити самостійні шляхи відображення художнього образу у продукті. Тим самим утверджуючи, що у дитині розвивається свобода вибору, самостійність i, насамперед, фантазія і творчі навички. Але такий підхід актуальний і набуває значення, коли дитина 
дошкільного віку вже оволоділа технічними засобами i навичками для використання художніх матеріалів.

Адже, якщо звернутись до Л. Виготського, який зазначив, що розвиток фантазії і творчих здібностей формується на попередньому досвіді, а саме на прикладах i повторюваннях за зразками і тільки через опанування певних навичок дитина може створювати власний продукт, який буде відповідати дійсно естетичним еталоном і поступово формувати іiі творчі здібності (Vygotskij, 1997).

Необхідно підкреслити, що без певних уявлень щодо естетичних смаків продукту у дитини дошкільного віку закладається хибне враження щодо краси навколишнього світу. Так само, дослідник В. Ворожбіт в історикопедагогічній проекції продемонструвала значимість опори у дитячій художньо-продуктивної діяльності на загальнолюдські константи краси технік виконання образотворчої і прикладної діяльності, мудрості у виборі альтернативних проявів творчості (Vorozhbit, 2012).

На нашу думку, перш, ніж надати дитині творчу свободу, необхідно навчити і показати їй, що вважається красою, як від кольору фарб може змінюватись картина, як рух і міміка може передати настрій персонажу, як музика впливає на формування і сприйняття світу. Вихователь дає орієнтир, спрямовує вихованців на життєвій успіх, продуктивну діяльність.

Обговорення. Художньо-продуктивна діяльність - це перша сходинка до формування творчих навичок, яка складається 3 таких компонентів: образотворчого, музичного, літературного, театралізованого. Кожен компонент розподіляться на декілька елементів. Наприклад, у музичній діяльності - сприйняття музики і співу, гри на музичних інструментах, танців, хороводу. В образотворчій - сприйняття картин, малювання, ліплення, аплікація; у літературній - слухання казок, розповідей, читання віршів, складання розповіді за сюжетними картинами. Компоненти формують не тільки образ, а й мають значний вплив на формування естетичних смаків, емоційного стану дитини. Набуті навички художньопродуктивної діяльності розкриваються у творчих здібностях упродовж усього життя. Адже батьки і вихователі повинні плекати унікальні здібності дітей: уяву, творчість. У майбутньому дитина має давати собі раду таким же способом, як і в даний момент. За словами Кена Робінсона «те, ким ми станемо завтра, залежить від того, що ми переживемо тут і тепер» (Ken Robinson, 2017).

Висновки. Отримані результати проведеного дослідження свідчать, що основою художньо-продуктивної діяльності $є$ образне мислення. На цій основі формується досвід і практична компетенція художньо-продуктивної 
діяльності. Змістовна суть художньо-продуктивної діяльності - це використання художніх засобів. Форми прояву художньо-продуктивної діяльності відбуваються на перетині інших видів діяльності: продуктивної, художньої, предметно-практичної, художню-творчої, технічної, художньоестетичної. Результатом художньо-продуктивної діяльності виступає кінцевий продукт, який впливає на формування життєвої компетентності, пронизує усі напрями виховання. Перспективи подальших розробок у даному напрямі полягають у визначенні сформованості життєвої компетенції у дітей старшого дошкільного віку через художньо-продуктивну діяльність.

\section{ЛІТЕРАТУРА:}

Ворожбіт В.В. Духовно-моральне виховання дітей у загальноосвітніх закладах України (історико-педагогічний аспект) : Наукова монографія. Х. : Основа, 2012. 328 с.

Выготский Л. С. Воображение и творчество в детском возрасте. Санкт-Петербург, 1997. 96 с.

Державний Базовий компонент дошкільної освіти в Україні (нова редакція) [Електронний pecypc]. Режим доступу: https://mon.gov.ua/storage/app/media/doshkilna/bazovijkomponent-doshkilnoyi-osviti-na-sajt-ostatochnij.pdf

Естетика : Підручник. За заг. ред. Л. Т. Левчук. 2-е вид. К. : Вища школа, 2005. 431с.

Кен Робінсон. Освіта проти таланту. Сила творчості. Львів : Літопис, 2017. 256 с.

Наказ Міністерства освіти і науки України від 20.04.2015 № 446 «Про затвердження гранично допустимого навчального навантаження на дитину у дошкільних навчальних закладах різних типів та форми власності» [Електронний ресурс]. Режим доступу: https://zakon.rada.gov.ua/laws/main/z0520-15

Поніманська Т. І. Дошкільна педагогіка: підручник. 2-ге вид., К. : Академвидав, 2013. $464 \mathrm{c.}$

Рубинштейн С. Л. Основы общей психологии. СПб : Питер, 2000. 712 с.

Степанов О. М., Фіцула М. М. Основи психології і педагогіки : Навчальний посібник. К. : Академвидав, 2005. 520 с.

\section{REFERENCES:}

Vorozhbit, V. (2012) Dukhovno-moralne vykhovannia ditei u zahalnoosvitnikh zakladakh Ukrainy (istoryko-pedahohichnyi aspekt) [Spiritual and moral upbringing of children in secondary schools of Ukraine (historical and pedagogical aspect)]. Naukova monohrafiia. Kharkiv : Osnova (in Ukranian).

Vygotskij, L. S. (1997) Voobrazhenie i tvorchestvo $v$ detskom vozraste. [Imagination and creativity in childhood]. Sankt-Peterburg (in Russian).

Derzhavnyi Bazovyi komponent doshkilnoi osvity v Ukraini (nova redaktsiia) (2016) [State Basic Component of Preschool Education in Ukraine (revised)]. Retrieved from https://mon.gov.ua/storage/app/media/doshkilna/bazovij-komponent-doshkilnoyi-osvitina-sajt-ostatochnij.pdf (in Ukranian).

Levchuk, L. T. (Ed.) (2005) Estetyka. [Aesthetics]. Pidruchnyk. 2-e vyd. K. : Vyshcha shkola (in Ukranian).

Ken Robinson (2017) Osvita proty talantu. Syla tvorchosti. [Education against talent. The power of creativity]. Lviv : Litopys (in Ukranian).

Nakaz Ministerstva osvity i nauky Ukrainy (2015, April 20) Pro zatverdzhennia hranychno dopustymoho navchalnoho navantazhennia na dytynu u doshkilnykh navchalnykh 
zakladakh riznykh typiv ta formy vlasnosti. [On approval of the maximum allowable educational load per child in pre-school educational institutions of different types and forms of ownership]. Retrieved from https://zakon.rada.gov.ua/laws/main/z0520-15 (in Ukranian).

Ponimanska, T. I. (2013). Doshkilna pedahohika. [Preschool pedagogy]. Pidruchnyk. 2-he vyd., Kyiv: Akademvydav (in Ukranian).

Rubinshtejn, S. L. (2000) Osnovy obshhej psihologii. [Fundamentals of General Psychology]. $\mathrm{SPb}$ : Piter (in Russian).

Stepanov, O. M. \& Fitsula, M. M. (2005) Osnovy psykholohii i pedahohiky. [Fundamentals of psychology and pedagogy]. Navchalnyi posibnyk. K. : Akademvydav (in Ukranian).

Інформація про автора:

Штефан Марина Владиславівна

ORCID: https://0000-0002-0304-1567,

Аспірант кафедри історії педагогіки та

порівняльної педагогіки, Харківського національного педагогічного університету імені Г.С. Сковороди,

вул. Валентинівська, 2, 61000

e-mail: shtefan.maris@gmail.com

\section{Information about the author:} Shtefan Maryna Vladyslavivna

ORCID: https://0000-0002-0304-1567, PhD candidate of the Department of History of Pedagogy and Comparative Pedagogy, Ukraine, Kharkiv, Street Valentynivska, 2, H. S. Skovoroda Kharkiv National Pedagogical University, 61000

e-mail: shtefan.maris@gmail.com

Цитуйте цю статтю як: Штефан М.В. Зміст поняття художньо-продуктивної діяльності дітей старшого дошкільного віку. Теорія та методика навчання та виховання. 2019. № 47. C. 201-210.

DOI: DOI: $10.34142 / 23128046.2019 .47 .18$

Дата надходження статті до редакції: 27.11.2019

Стаття прийнята до друку: 13.12.2019 